\title{
Pathways to climate stabilisation
}

\section{Sørensen, Bent}

\section{Published in: \\ Energy Policy}

DOI:

10.1016/j.enpol.2008.05.028

\section{Publication date:}

2008

\section{Document Version}

Early version, also known as pre-print

Citation for published version (APA):

Sørensen, B. (2008). Pathways to climate stabilisation. Energy Policy, 36(9), 3505-3509.

https://doi.org/10.1016/j.enpol.2008.05.028

\section{General rights}

Copyright and moral rights for the publications made accessible in the public portal are retained by the authors and/or other copyright owners and it is a condition of accessing publications that users recognise and abide by the legal requirements associated with these rights.

- Users may download and print one copy of any publication from the public portal for the purpose of private study or research.

- You may not further distribute the material or use it for any profit-making activity or commercial gain.

- You may freely distribute the URL identifying the publication in the public portal.

\section{Take down policy}

If you believe that this document breaches copyright please contact rucforsk@kb.dk providing details, and we will remove access to the work immediately and investigate your claim. 


\title{
Pathways to climate stabilisation
}

\section{Bent Sørensen}

Energy, Environment and Climate Group, Department of Environmental, Social and Spatial Change, Roskilde University, 4000 Roskilde, Denmark. E-mail: boson@ruc.dk Web: http://energy.ruc.dk

\begin{abstract}
Global climate warming mitigation efforts are more likely to be successful if they are based on per capita emissions rather than on complex negotiated emission rights. I propose a path to temperature stabilisation optimised for each country and reaching a common per capita rate of greenhouse gas emissions by the end of the $21^{\text {st }}$ century. Consistent emission pathways for given levels of temperature stabilisation are calculated by use of a simple model that is consistent with the circulation models and data sets surveyed by the Intergovernmental Panel on Climate Change. The allowable emissions are detailed on a regional level and on individual country level. I discuss the merits of this type of approach relative to other policy approaches, as well as some of the objections that may be voiced.
\end{abstract}

Keywords: Climate policy, emissions scenarios, temperature stabilisation

\section{Introduction}

Country-by-country individual $\mathrm{CO}_{2}$-emission targets, such as those recently suggested by the EU, are bound to create problems, both as concerns agreement, extendibility to 
the rest of the world, and probability of actually being carried through. The individual targets are based on factors such as current economic situation and growth, and to some extent the present use of renewable or nuclear energy. When non-compliance becomes evident, we will hear excuses such as "our economic growth was higher (or lower) than assumed in setting the targets" or "our targets were anyway set too high in comparison with those of Romania".

Let me suggest instead an approach, which is both simple and easy to understand, and which therefore has a chance of working in the real world, namely to introduce a common ceiling on per capita greenhouse gas emissions, along with optimal pathways allowing each country to reach the ceiling before a specified date. The advantages of a per capita approach have been aired in connection with previous climate summits, but no political action has pursued. A number of possible objections to the idea will be discussed below. First I use the IPCC modelling methodology to explore the characteristics of such an approach to climate stabilization.

\section{Pathways derived from simple climate model calculations}

The models reviewed by IPCC try to establish a connection between stabilisation of the global temperature average (and other climate impacts) at a given level, the corresponding equilibrium concentration of greenhouse gases in the atmosphere, and the allowable $\mathrm{CO}_{2}$-emissions and other climate-altering human activities, that policies have to ensure in order to reach stabilisation at the desired level. The general circulation models used in climate science proceeds from given emissions to calculated atmospheric concentrations, from which temperature changes are determined. Thus one would have to look at many calculations with specific emission assumptions in order to 
find those, for which the average temperature reaches say $1.5^{\circ} \mathrm{C}$ above the year-2000 average temperature level (which translates to some $2.1^{\circ} \mathrm{C}$ above the pre-industrial level). They would require a stable $450 \mathrm{ppm}$ level of $\mathrm{CO}_{2}$ in the atmosphere (some 500 ppm if other greenhouse gases are included), with the uncertainty induced mainly by model accuracy but also by the different residence time of different greenhouse gases and the changes in cooling associated with particulate emissions from industry or from volcanoes. It follows that anthropogenic emissions of greenhouse gases would have to be radically reduced (Solomon et al , 2007; Metz et al., 2007). The reverse calculation from a given temperature stabilisation to the implied allowable emissions profiles (emissions as function of time) is not unique but requires additional assumptions, such as mitigation costs and technology readiness, in order to allow the determination of an optimal path to stabilisation.

Figure 1 shows such global average stabilisation routes calculated in terms of $\mathrm{CO}_{2}$ emission profiles of various policies for reaching a stable situation before year 2100, with average surface temperature increases in the range of 1.0 to $2.5^{\circ} \mathrm{C}$. These temperature rises are relative to year 2000 and the model assumes similar reduction in other greenhouse gases. The emissions in Fig. 1 are shown per capita, i.e. global emissions divided by global population for a given year. The historic data are those used by the IPCC, and the $21^{\text {st }}$ century values are calculated using a simple model called the Java Climate Model (Matthews, 2008). It very well reproduces the results of earlier IPCC assessments and the results given in Fig. 1 are consistent with the simulations presented in the most recent IPCC report (Metz et al., 2007). Detailed comparison is not possible because the IPCC report only gives ranges of results for a selection of literature emission scenarios, whereas the present calculation determines the emissions leading to 
a precise level of warming dynamically by iterating the approach to stabilization. The present calculation uses a population development reaching $10^{10}$ by the end of the $21^{\text {st }}$ century, like in the IPCC “B2" scenario (Metz et al., 2007). The calculation behind Fig. 1 further assumes that per capita emissions converge towards a common value and reach it at or shortly after year 2100 . The emission pathway to be followed by different regions of the world is depicted in Fig. 2, for the $1.5^{\circ} \mathrm{C}$ warming calculation of Fig. 1. The same on an individual country level is contained in spreadsheet-form in the Electronic Annex, along with the input data for the computer model. The calculation takes into account the ability of different economies to mitigate greenhouse gas emissions, and mitigation therefore starts a little earlier in the most technologically advanced regions.

The stabilization corresponding to the $1.5^{\circ} \mathrm{C}$ case of Fig. 1 can thus be achieved by imposing the increasingly strict (as function of time) per-capita emission limits as shown in Fig. 2 for each region of the world or for each country. The limits start at the current level of emissions and converge to the common goal value by the end of the $21^{\text {st }}$ century. Legislation can be introduced in each country to impose the diminishing ceiling either individually or collectively. The time-wise accumulated emissions on a regional basis are given in Table 1, but it would be wise to monitor compliance by requiring the sliding targets to be met say by the end of each decade, in order to detect any noncompliance and implement penalties such as trade embargos, provided these measures have been agreed. The concurrent reduction of non- $\mathrm{CO}_{2}$ greenhouse gas emissions is shown in Fig. 3, for the $1.5^{\circ} \mathrm{C}$ case.

Clearly, not only emissions from national activities (raw materials extraction, production, transport and consumption) should be considered, but also emissions from 
international air and ship traffic. To include these emissions in the national emission budget of each country, which also includes the corresponding transport activity in its activity measure (such as GNP), is a straightforward extension of the current method of accounting in the international climate negotiations. It would substantially increase emission counts for countries with large shipping industries, such as Denmark, but would similarly show up as economic activity in GNP accounting. There are at least two other ways of allocating emissions. $a$ : to ascribe emissions to the financial owners of each activity, or $b$ : to ascribe the emissions to those using or benefiting from the product or service causing the emissions (along its life-cycle). Providing data for these alternative accounting principles is more difficult that for the method currently in use, but not impossible given the wealth of statistical data available (for $a$, emissions from enterprises would be distributed on shareholders according to country affiliation, while for $b$, the emissions from production and transport would be distributed on the final consumers according to country or residence, as derived from trade statistics). Method $b$ would increase emission allocations to countries outsourcing energy-intensive production to other parts of the world, and would decrease emissions for those developing countries carrying out such energy-intensive production but exporting most of the products. The calculations presented in this communication all use the conventional accounting by country of performed activity.

Regarding the overall feasibility of achieving the necessary reductions in emission of greenhouse gases, several detailed scenarios have been worked out to show that the implied phasing out of emissions is indeed technically possible, economically affordable and compatible with continued increase in living standards, everywhere (Sørensen and Meibom, 2000; Sørensen, 2004; 2005; 2007). 


\section{Discussion of possible objections to the per capita approach}

Are there caveats in this approach? Looking at the historical part of the per capita emissions in Fig. 1, one notes that the per capita emissions have risen remarkable little during the $20^{\text {th }}$ century, obviously due to the explosive development of the world population and massive poverty in many parts of the world, with the associated smallness of emissions. Population increase is a main reason for the lack of success in creating economic welfare for all the inhabitants of the world, and economic disparity has increased rather than decreased. Does the population increase make it easier for the rich to continue high greenhouse gas emissions? The answer is that this is not the case even when the regional per capita emissions are used to regulate future emissions, as assumed in Fig. 2. Countries in North America or Australia will have to use their technological skills to accomplish a rapid but realistic decrease in emissions, while the less developed countries have lesser per capita reductions prescribed. However, there is no invitation to avoid using mitigating technology, because the current inefficient use of land and energy already lead to emissions above the target. These developing countries may complaint that the scheme does not allow them to increase their emissions to US levels before doing something about the problem, but that is precisely the intent: move directly towards the stable situation without detours that may form bad habits clouding the future efforts. The proposed ceilings are proper and realistic because a country seeking high economic growth must invest in new equipment and processes and thus may as well choose the right solution right away. Reasoning that the proper solutions are more expensive is false because the expenses will have to be paid anyway, and may be higher the longer one waits. It has also been suggested that the long-industrialized 
countries should pay for the sins of the past (grand-fathering), but after all precise knowledge of the global warming effects has only been available for about 40 years, and the suggested scheme anyway demands a very rapid mitigation from the rich nations.

Would a scheme like the proposed one encourage nations to increase their population in order to get higher emission allowances? That is hardly the case, because the greenhouse mitigation costs are in any case small compared to the efforts needed to create economic welfare for more people. There is also no reason to compensate regions with lower than average population density, as this is usually a consequence of land areas hard to populate (examples are in Arctic or desert regions). Avoiding overpopulation should in any case be a primary target in any region of the world. Population stabilization must be a strong international priority with efforts at least as serious as in the case of greenhouse gas emissions. The fact that food production growth until now has on average kept up with population increase (although not necessarily the distribution of food to all) does not mean that it will continue to be possible or environmentally sustainable (Friedlingstein, 2008).

The tradable emission-permits envisaged by some current greenhouse abatement schemes would hardly be needed for the scheme I suggest. They aim at having investments made in the order of increasing abatement cost and would typically move investments from the countries with large emissions to less developed nations, where the equipment installed may not be used properly and thus not be achieving the proposed emission reductions. The time-scale on which greenhouse gas emissions have to be dramatically reduced is so short, that fiddling with the succession of investments seems quite unimportant. The high-emission countries have the skills and should reduce 
their own emissions as quickly as possible, which is exactly what the proposed scheme can accomplish. Tradable permits constitute an attempt to force the greenhouse problem into a framework of $19^{\text {th }}$ century liberal economic theory, assuming that the market will solve any and all problems. We know that this is not true, and the global warming damage is a perfect example of the need to base political action on more than antiquated economic dogmas.

\section{References and notes}

Friedlingstein, P. A steep road to climate stabilization. Nature 451, 297-298 (2008).

Matthews, B. The Java Climate Model, v5. Software available from http://www.climate.be (assessed Jan. 2008).

Metz, B. et al. (eds.) Climate Change 2007. Mitigation. Contribution of Working Group III to the $4^{\text {th }}$ Assessment Report of the Intergovernmental Panel on Climate Change. Particularly Ch. 3 (Cambridge Univ. Press, Cambridge, UK, 2007).

Solomon, S. et al. (eds.) Climate Change 2007. The physical science basis. Contribution of Working Group I to the $4^{\text {th }}$ Assessment Report of the Intergovernmental Panel on Climate Change. Particularly Ch. 10 (Cambridge Univ. Press, Cambridge, UK, 2007).

Sørensen, B. Renewable Energy. $3^{\text {rd }}$ ed. (Elsevier Academic Press, Burlington, USA, 2004).

Sørensen, B. Hydrogen and Fuel Cells. (Elsevier Academic Press, Burlington, USA, 2005).

Sørensen, B. A sustainable energy future: Construction of demand and renewable energy supply scenarios. A renewable energy and hydrogen scenario for northern Europe. Int. J. Energy Research (DOI 10.1002/er. 1375 and 1376, published online 2007).

Sørensen, B., and Meibom, P. A global renewable energy scenario. Int. J. Global Energy Issues 13, 196-276 (2000).

Electronic Annex: Spreadsheet with individual country emissions, and computer input file. 
Table 1 . Total allowable emissions for the entire $21^{\text {st }}$ century and number of years that the allowed $\mathrm{CO}_{2}$ emissions of each region could continue at constant 2007-level, provided that it is reduced to zero after that time span.

\begin{tabular}{|l|l|l|}
\hline $\begin{array}{l}\text { Stabilisation by 2100 at 1.5 } \\
\text { deg. C above 2000-level }\end{array}$ & $2000-2100\left(G t \mathrm{CO}_{2}\right)$ & Years to zero- $\mathrm{CO}_{2}$ allowance \\
\hline United States & 255 & 42 \\
\hline Canada Australia New Zealand & 44 & 30 \\
\hline Japan & 65 & 49 \\
\hline West Europe & 179 & 50 \\
\hline East Europe B & 34 & 49 \\
\hline Russia Ukraine Belarus & 78 & 39 \\
\hline Middle East & 161 & 79 \\
\hline China & 250 & 64 \\
\hline Other Asia & 155 & 76 \\
\hline India & 183 & 144 \\
\hline Latin America & 86 & 41 \\
\hline Africa & 213 & 61 \\
\hline Int. Ship/Air & 80 & 95 \\
\hline World & 1783 & 615 \\
\hline
\end{tabular}




\section{Figure captions}

Figure 1. Per capita $\mathrm{CO}_{2}$ emissions leading to a global warming between 1 and $2.5^{\circ} \mathrm{C}$ relative to year 2000. Population development indicated at top.

Figure 2. Regional per capita $\mathrm{CO}_{2}$ emissions leading to stabilization of global warming $1.5^{\circ} \mathrm{C}$ above the level in year 2000. Upper panel: current high-emission regions. Lower panel: present low-emission regions.

Figure 3. Per capita total emissions expressed as $\mathrm{CO}_{2}$-equivalent ones for the model calculation leading to a global warming stabilising at $1.5^{\circ} \mathrm{C}$ above the year-2000 average temperature, and for comparison the $\mathrm{CO}_{2}$-emissions alone, used in Figs. 1 and 2.

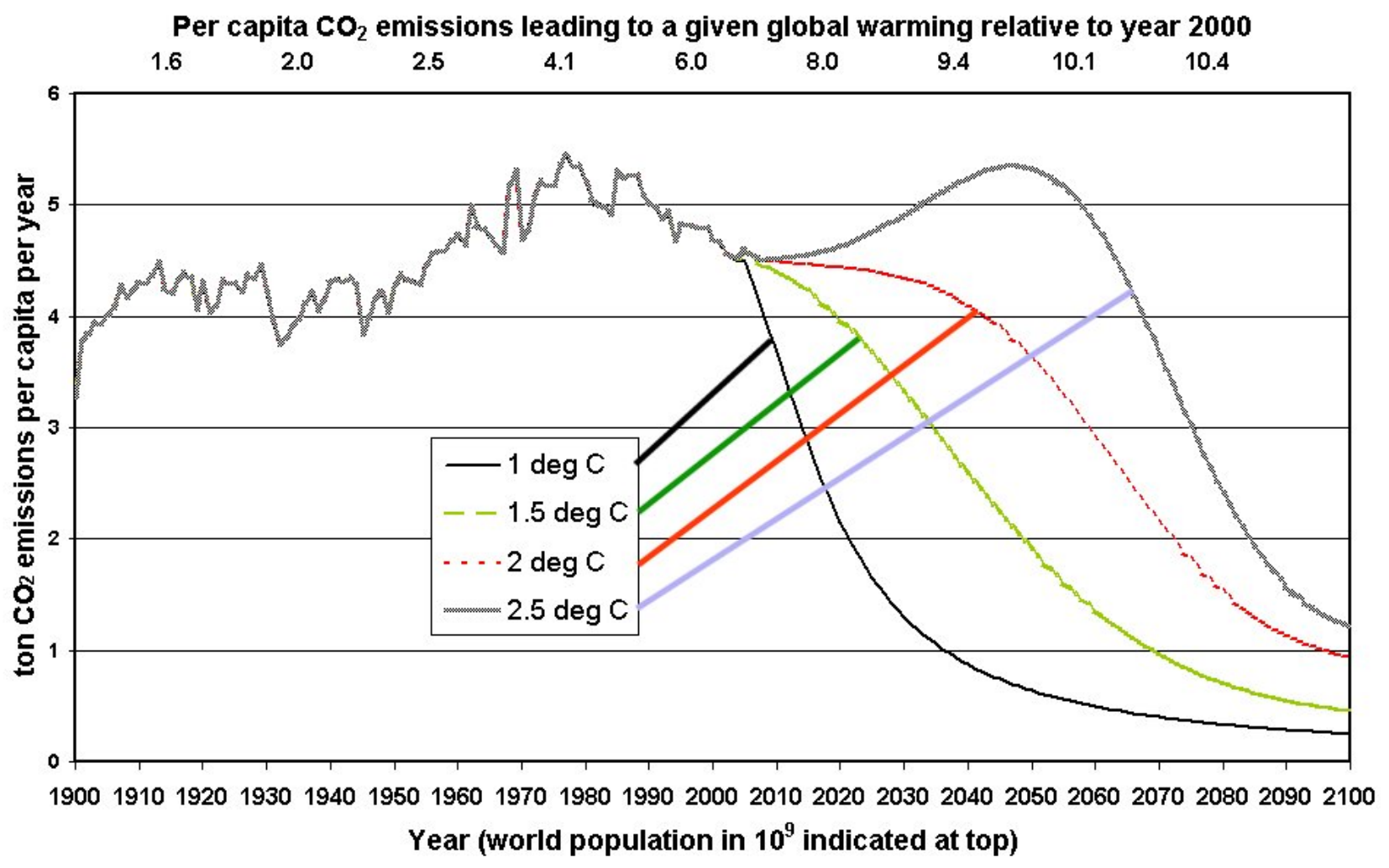



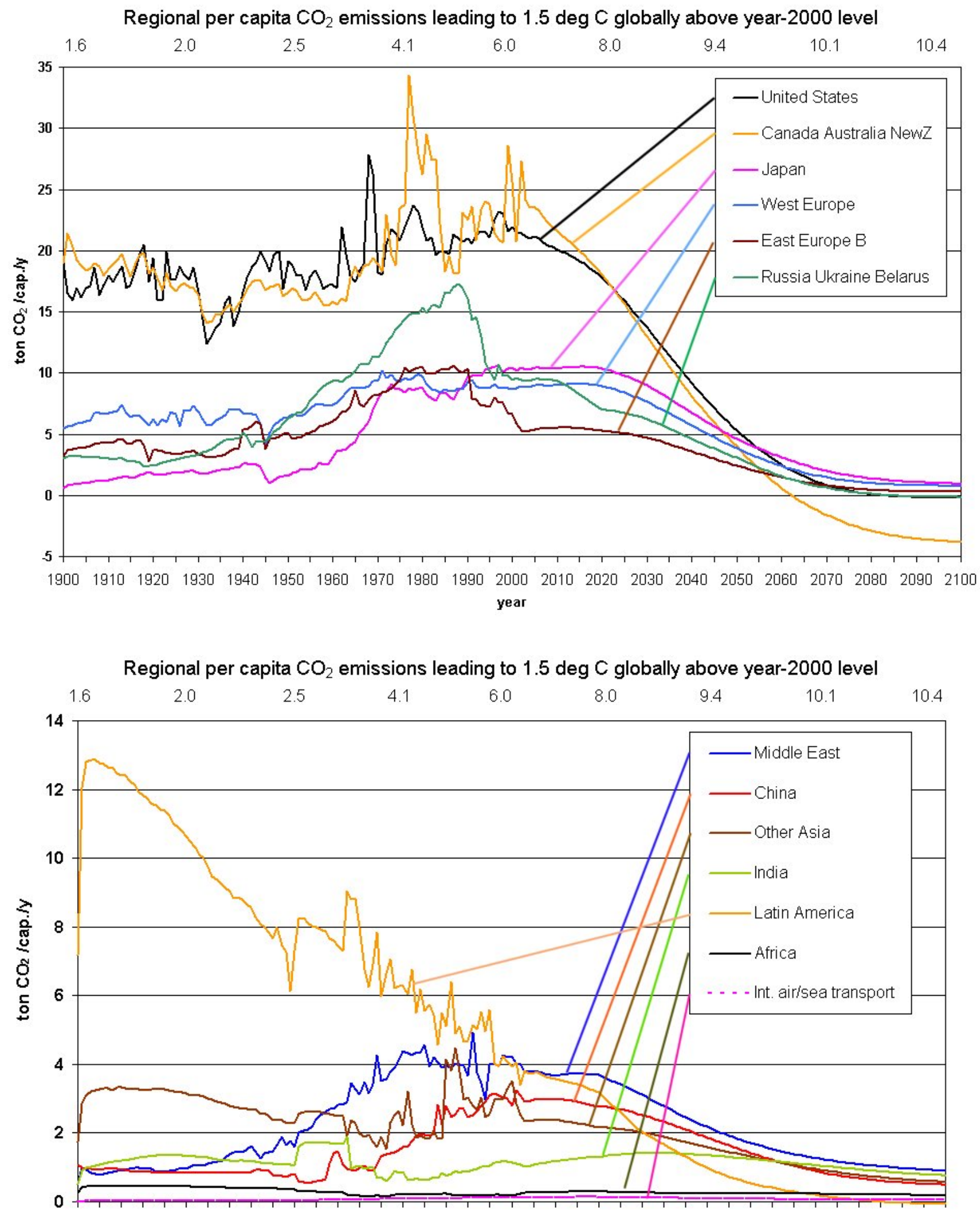

$190019101920193019401950 \quad 1960 \quad 1970 \quad 1980199020002010202020302040205020602070208020902100$ year 
Per capita $\mathrm{CO}_{2}$ emissions leading to $1.5 \mathrm{deg} \mathrm{C}$ global warming relative to year 2000

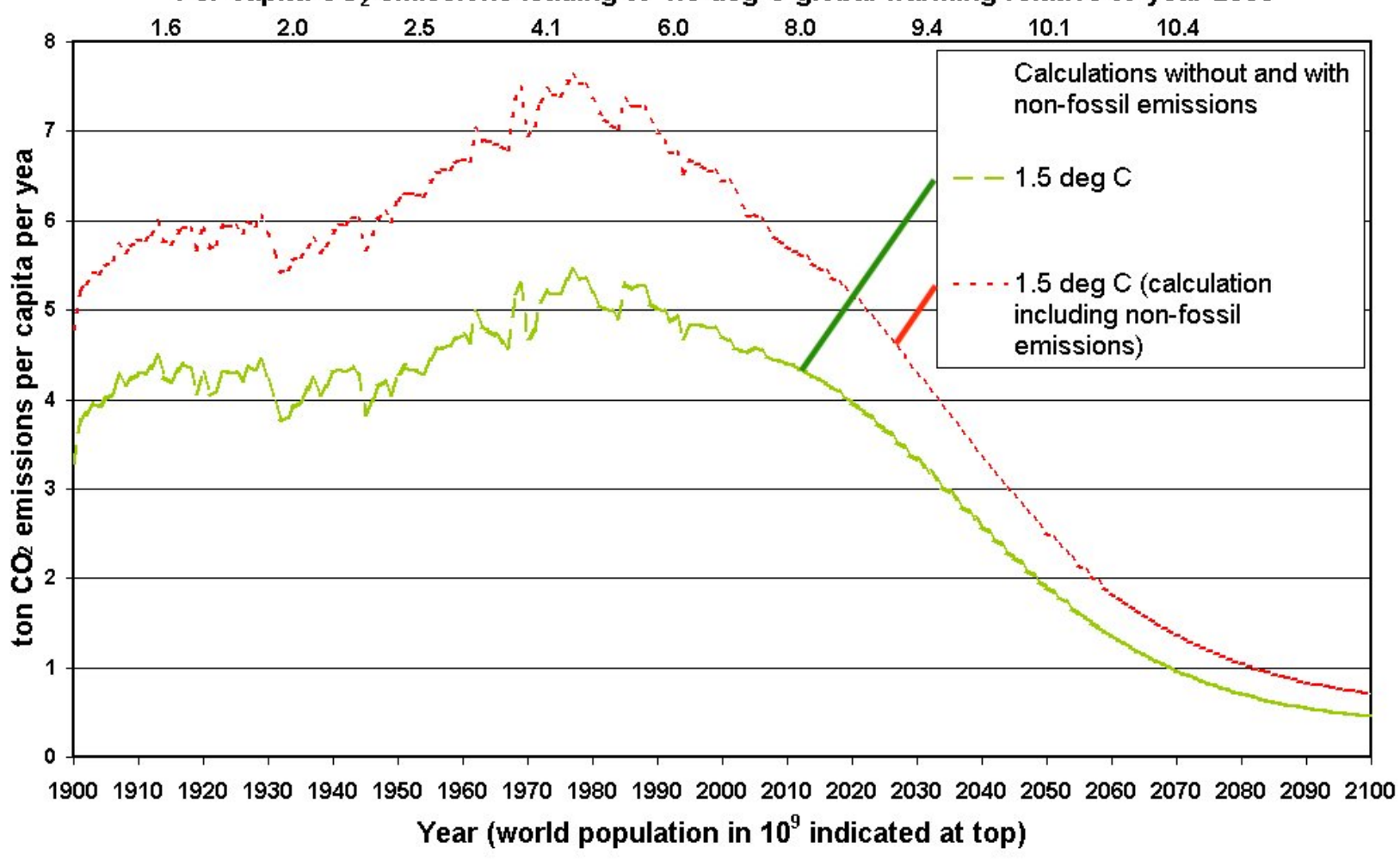

